Research Article - Public Research Institute for the Blind

\title{
TECHNIQUES ON USING MOBILE DEVICES FOR THE BLIND’S LANGUAGE LEARNING
}

\author{
Steina Melie \\ Public Research Institute for the Blind \\ Corresponding email: steinamelie@prib.org
}

\begin{abstract}
Electronic aids on mobile devices are starting to spread to the visually impaired including for language learning. However, they may have the disadvantage of only providing information on the vocabularies and sentences, and not on the other language elements. The non-visual guidance assistance techniques developed on mobile phones can provide these missing indications. They are intended to allow a user to determine the contexts in which the language used especially for the information related to the language interaction.
\end{abstract}

Keywords: electronic aids, language learning, mobile device, visual impairment.

\section{FULL TEXT}

\section{APA CITATION:}

Melie, S. (2020). Interaction techniques on mobile devices for the blind's language learning. Journal of Learning and Technology Application, 10(1), 32-47. 


\section{Disclosure statement}

No potential conflict of interest was reported by the author.

\section{References}

Brock, A. M. (2013). Designing interactive maps for visually impaired people. Accessibility and Computing, 105, 9-14.

Florian, L. (2008). Special or inclusive education: Future trends. British Journal of Special Education, 35(4), 202-208.

Gabel, S. L. (2005). Disability studies in education: Readings in theory and method. New York, NY: Peter Lang.

Jenks, E. B. (2005). Parents' stories of raising children with visual impairments in a sighted world. Journal of Contemporary Ethnography, 34, 143-169.

Masino, S., \& Zarazúa, M. N. (2016). What works to improve the quality of student learning in developing countries? International Journal of Educational Development, 48, 53-65.

Melie, S., William, G., Susanto, S., \& Nanda, D. S. (2020). Foreign language training for visually impaired students in South East Asian countries. https://doi.org/10.31219/osf.io/vjrng.

Nanda, D. S. (2016, May). Fostering the Use of Drama for English Language Learners in the Efl Classroom. In International Conference on Education and Language (ICEL) (p. 7).

Nugent, M. (2018). Reframing inclusion: An exclusive-inclusive approach. British Journal of Special Education, 45(2), 141-156. 
Pielot, M., Poppinga, B., \& Boll, S. (2012). Studying tactile navigation systems in-situ. Proceedings of $\mathrm{CHI}$.

Siebers, T. (2006). Disability theory. Ann Arbor, MI: University of Michigan Press.

Susanto, S. (2016). A case study of prosodic phrasal grouping and intonational prominence in language acquisition. English Review: Journal of English Education, 4(2), 289-295.

Susanto, S., \& Nanda, D. S. (2018). Teaching and learning English for visually impaired students: an ethnographic case study. English Review: Journal of English Education, 7(1), 83-92.

Thompson, R. G. (1997). Extraordinary bodies: Figuring physical disability in American culture and literature. New York, NY: Columbia University Press.

Weber, A., Braun, B., \& Crocker, M. W. (2006). Finding referents in time: Eye-tracking evidence for the role of contrastive accents. Language and Speech, 49(3), 367-92.

Whitburn, B. (2014). Accessibility and autonomy preconditions to 'our' inclusion: A grounded theory study of the experiences of secondary students with vision impairment. Journal of Research in Special Educational Needs, 14(1), 3-15.

Zhou, M. (2016). The roles of social anxiety, autonomy, and learning orientation in second language learning: A structural equation modeling analysis. System, 63, 89-100. 